\title{
TYPING THE SETTLEMENTS OF HOMOKHÁTSÁG
}

\section{Sándor Szombathelyi}

$\mathrm{PhD}$ student

\author{
Doctoral School of Economics and Regional Science, Faculty of Economics and Social \\ Sciences, Szent István University \\ E-mail: szombathelyi.sandor@gmail.com
}

\begin{abstract}
The status, problems and break out points of the Homokhátság have been examined by Bálint Csatári and his colleagues many times before. The uncategorized rural area in the classical interpretation is in big trouble because it should preserve its uniqueness and beauty despite the risk of desertification and the negative effects of the new age globalization. Studies and examinations are necessary so decision makers can get appropriate help and information to create effective action plans reinforced with financial plans which are Homokhátság specific and could achieve sustainable rural development based on the resources of the rural economy. The issues and methods of settlement categorisation are already known and have existed for a long time. This factor and cluster analysis executed in the SPSS application gives one answer to them. This article provides one possible solution to this problem.
\end{abstract}

Keywords: Homokhátság, typing, rural economy

JEL classification: $R 11$

LCC code: HT401-485

\section{Introduction}

Events of the past centuries (world wars, socialism, globalisation, climate change etc) have shaped the ecology, economy and society of rural settlements in many times and in many aspects. However, the effects of these events and processes have appeared differently in the rural settlements because these settlements have different amount and quality of rural economical resources. Because the settlements that make up the countryside are diverse and different, a unified countryside and rural economy do not exist for this reason either. I believe the statements of Park and Cloke (1985) are still valid to this day, meaning that the problem of the concept of the unified rural area can be traced back to the following reasons:

- One of the most important features of the rural area is change, due to the ever changing social behaviour towards the countryside and the close connection between social, economical and technological development with the countryside.

- Different definitions are made because the rural area and rurality can be approached from many sides. An economist, a sociologist and a rural developer all see something else.

- The rural character also inculdes changes in space, which is why the definitions need to take into account spatial differences as well. Rural areas can be different even within countries, not only within continents.

Regardless of this, many attempts were made to identify the rural area. The first common criteria were the low population density and primarily agricultural land usage. I believe the most appropriate Hungarian rural area definition is made by Bálint Csatári: „,... the rural area should be defined as an integrated or complex spatial (partly agricultural) development target area.” „The Hungarian countryside is well divided into regions." (Csatári, 1999, Káposzta, 
2020) According to Csatári, regional segmentation, regional identity and settlement structural features should all be taken into consideration when identifying rural areas, such as small villages, farms and agricultural cities. He also highlights that when creating a definition - while also satisfying the expected need for EU conformity - we should use the most simple and straightforward indicators to define the Hungarian rural small regions and its acceptable national features. He believes that rural regions should not be identified on the settlement level but on the small regional level instead, in order to avoid the indicator values of settlements rising above the ,generally accepted rurality”.

Because the rural economy expression contains the word ,rural” in it, this expression also lacks a unified definition. To better understand it, I used the definition of ,region” from the regional economics sciences, where it is defined as a collective concept that can be interpreted flexibly (Lengyel-Rechnitzer, 2004, Szücs-Káposzta, 2018). Similar to the rural area and the rural economy expressions, the expression of region is defined in many ways too. However, there seems to be an agreement about that all three spatial delimitations are a coherent, delimitable units of space. Krisztián Kis also wrote about this, saying that the rural area is part of the geographical space which is ,a unique, complex, environmental, economical and social space unit" (Kis, 2013). We can interpret all this to conclude that the rural economy can be considered as a regional economy as well. Lajos Fehér defined this in 2005 too, when he expressed that the rural economy can be found in rural areas and it is mostly a land use based regional economy where ,there is a central city and a connected rural countryside". According to his theory, it contains:

- participants of economical activities (producer, service, organiser) and consumers in a given area

- available and used resources for these activities in a given area

- enterprises, companies, households, non-governmental and official organizations, institutions representing the organizational framework of the economy

- system of relations with each other and with actors and organizations outside the area

- $\quad$ and those structures (sectoral, land usage, resource, cooperation, coordination etc) that take up the general framework of economical activities". (Fehér, 2005)

Kis Krisztián (2013) highlights that ,...due to the diversity of rural areas, we are not just talking about a rural economy in general but many rural economies instead emphasising their uniqueness and diversity." This definition may let us to the conclusion that the rural economy is one kind of space unit as well.

József Káposzta writes about the restructuring of the rural economy as follows:

Thanks to the economical growth in the last three decades, the „necessity scale has changed, the needs have changed, many new consumer habit have surfaced which with the spread of the idea and institutions of the welfare state, it emerges as a natural need" (Káposzta, 2015, Káposzta-Honvári, 2019). Due to globalisation, this change can be discovered in smaller villages as well. Jószef Káposzta documents this in detail in his study written in 2015: „Along these globalised trends, we can witness subsantial economical and social erosion in rural areas where local communities constantly lose their service and community institutes, schools and traffic infrastructures. Their environment based activities are have fallen behind: their natureadapting agriculture and tradition-built food production can only be found in traces and their ability to absorb funds is virtually non-existent. Due to all of this and the constant fund absorbtion of central regions, the impoverishment of the peripheries and the vulnerability of its society to employment, food, water and energy supply has become increasingly serious. Life in 
the countryside has now become equal to disadvantage in public thinking." (Káposzta, 2015). According to Krisztián Ritter, the European economical spatial structure has shifted and regional policies have gained a bigger role due to globalisation. ,The change and appreciation of regions and local areas is another fundamental consequence of globalization which results in that the setting of these conditions is not only the responsibility of governments anymore but the task of settlements and regions as well, thanks to the bigger ephasis on endogenous development theories and self-contruction." (Ritter, 2018)

\section{Resources and methodology}

The area of investigation is the $10.000 \mathrm{~km} 2$ in scope Homokhátság defined by Bálint Csatári, Ferenc Glatz and András Donát Kovács in 2004. This spatial unit consists of 104 settlements (Figure 1) divided to 3 counties: Bács-Kiskun with 61 settlements, Csongrád with 22 settlements and Pest with 21 settlements. According to this, the region can not be identified in an administrative sense and it is not included in the taxonomic classification of Hungary's natural landscapes either, making it a ,unique landscape category”. Its surface is mainly barren, and due to climate change it is already a semi-desert landscape. The Homokhátság is a highly sensitive area to climate change and the FAO of the United Nations has declared it a semidesert area in its long term review, with other studies foreshadowing the risk of desertification.

„Homokhát is both a natural formation and a man-made "cultural landscape" because its history and residents both transformed it to its present state." (Glatz et al, 2004) Due to the Tartar invasion in the 13th century, its settlement system was mostly destroyed and this landscape, with the great distance between the settlements, is still preserved. „Deforestation and the animal husbandry of market towns also contributed to the erosion of the surface, and later the appearance of river regulations, afforestation, and farmsteads, and then the change of agricultural cultivation accompanying collectivization shaped the landscape." (Glatz et al, 2004)

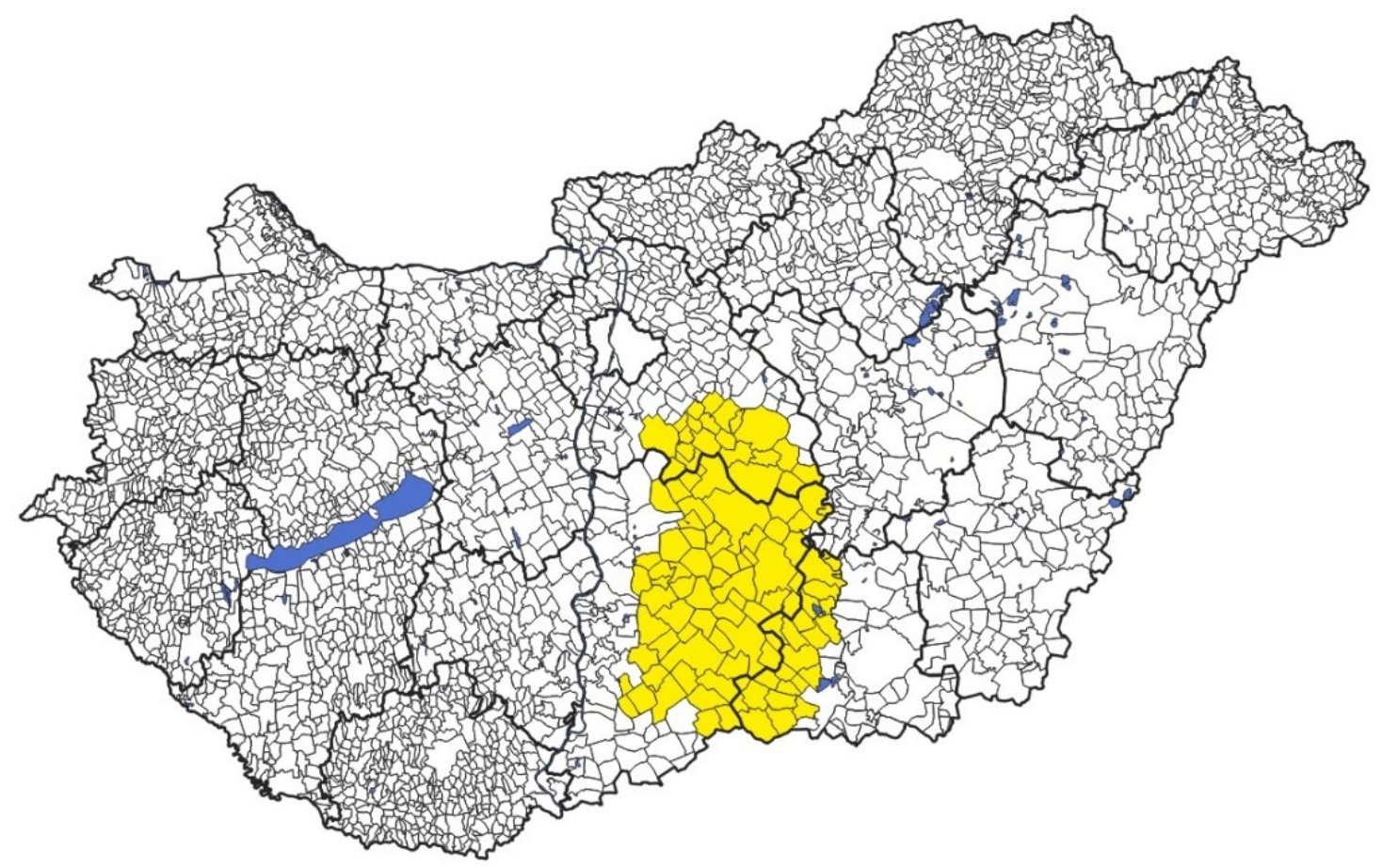

Figure 1: The 104 settlements of Homokhátság

Source: Glatz et al., 2004. 
The period of my study is from 1990 to 2015, a quarter of a century since the change of regime, in which the composition of the databases changed partly due to methodological changes. The indicators used for the analyses are mostly from the 1990 and 2011 censuses, respectively, but I deviated from this for several reasons. One reason was that the last census was almost a decade ago, so when I had more recent data, I used this instead (years 2014 and 2015). The data sources were the following: National Spatial Development Information System, Hungarian Central Statistical Office and Hungarian State Treasury (formerly known as Agriculture and Rural Development Office).

Data collection was further hampered by methodological changes in the indicators and the fact that some data collected in 1990 was no longer collected in 2011. Considering that a village was not an independent settlement back then, there was no relevant data for 1990; this problem needed to be dealt with as well. The incompleteness of the data made it difficult to carry out the secondary research, which also affects all settlements. In addition, I had to further select my indicators due to the sensitivity of the analysis methods for the factor and then cluster analysis done in IBM SPSS Statistics 23 application. I have selected the indicators in Table 1 despite these difficulties.

I believe these indicators are suitable for forming a complex and largely precise picture of the settlements and groups of settlements formed during the investigations.

Table 1: Indicators suitable for the factor analysis

\begin{tabular}{|l|}
\hline Variables used: \\
\hline Population density development between 1990 and $2015(\%)$ \\
\hline Proportion changes of those with a university or college degree between 1990 and $2011(\%)$ \\
\hline Proportion of unemployed between 1990 and $2015(\%)$ \\
\hline $\begin{array}{l}\text { Cumulative value of agriculture and rural development funds per capita between } 2004 \text { and } \\
2015 \text { (HUF) }\end{array}$ \\
\hline Development of net income per capita between 2004 and $2014(\%)$ \\
\hline $\begin{array}{l}\text { Changes in the rate of people not finishing first grade of primary school between } 1990 \text { and } \\
2011(\%)\end{array}$ \\
\hline Development of the commuting volume between 1990 and $2011(\%)$ \\
\hline
\end{tabular}

Source: Self edit 2019.

\section{Factor analysis}

Factor analysis makes the work easier in two ways: it reduces the number of variables and discovers the relationships between the variables too, so interpreting and applying them becomes easier. The advantage of the resulting factors is that more analyses can be done with them, which is a cluster analysis in my case. (Sajtos- Mitey, 2007) I could reduce the high number of variables with minimal information loss using main component analysis.

One of the basic conditions of the factor analysis is that the sample to be examined, in this case the number of settlements, must be at least ten times larger than the number of data variables.

Prior to running the analysis, it is necessary to check the integrity of the data used with several test methods. According to the correlation matrix, if the correlation is strong, then the variables are suitable for factor analysis. However, if they are too strong, all variables would fall into one factor and thus there would be no solution. It is essential to run the anti-image matrix to test the suitability of the variables, where the diagonal MSA values, measure of sampling adequacy, of 
its correlation table are governing. These values range from 0 to 1 and show the extent to which the various variables are related to each other; below 0.5 , the variable should be excluded from the study but above that it is appropriate to use. The KMO value (Kaiser-Meyer-Olkin) is the average of the MSA value for each variable. This means that the previous evaluation rule is applicable here as well with the stipulation that the variables considered suitable can be divided into five compliance categories.

During factor analysis, the components can share the information content more evenly by using varimax rotation, while the information content and significance level of the factors do not change. The factors do not correlate with each other this way.

Table 2: The main indicators of the applicability of factor analysis

\begin{tabular}{|c|c|c|c|}
\hline Nr of main components & KMO criteria & Sig. & Explained variance \% \\
\hline 3 &, 715 &, 000 & 66,6 \\
\hline
\end{tabular}

Source: Self edit, 2019.

\section{Cluster analysis}

In contrast to factor analysis, cluster analysis does not reduce the number of variables by merging them, but instead creates groups of settlements from a list of settlements.. One of the basis of the analysis is that the elements belonging to each group are similar to each other, while showing a difference from the elements belonging to other groups. However, cluster analysis has a number of limitations. This is why it should be stated that the result of the present study is not the only best solution for the typification of the settlements of Homokhátság in terms of rural economic restructuring. The limitations are the following:

- „No conclusions can be drawn for the population from the sample, it can only be used as an exploratory technique.

- There is no single best solution.

- It creates clusters in every case.

- The solutions depend on the variables.

- The formed groups depend on the order of the individual data in the database." (Csallner, 2015)

The cluster analysis was performed with the three factor coordinates obtained by the factor analysis using a non-hierarchical method, due to the high number of sampling units. In addition, hierarchical clustering creates nested clusters, which in turn is contrary to the independent examination of settlement types. According to László Sajtos, there is no clear answer to whether the hierarchical or non-hierarchical method is more recommended. ,The use of non-hierarchical methods is advantageous when the number of sampling units is high and the results obtained are less dependent on the outliners, the distance measure used, and whether an irrelevant variable has been included in the analysis." (Sajtos et al, 2007) The K-Means cluster used here differs from the hierarchical method in two main respects; the number of clusters must be determined in advance and the definition of the cluster center can be left to the program.

\section{Results}

\section{The result of the factor analysis}

Using factor analysis, three factors were created from the seven variables. I have listed them in Table 5, in addition to the corresponding factor contents and factor names to which they belong. 
Table 3: Factors of the settlements of Homokhátság

\begin{tabular}{|c|c|c|}
\hline Variables & $\begin{array}{l}\text { Factor content } \\
\text { of variables }\end{array}$ & Factor name \\
\hline $\begin{array}{l}\text { Population density development between } 1990 \text { and } 2015 \\
(\%)\end{array}$ & ,592 & \multirow{4}{*}{ Society } \\
\hline $\begin{array}{l}\text { Proportion changes of those with a university or college } \\
\text { degree between } 1990 \text { and } 2011(\%)\end{array}$ & ,795 & \\
\hline Proportion of unemployed between 1990 and $2015(\%)$ & ,807 & \\
\hline $\begin{array}{l}\text { Changes in the rate of people not finishing first grade of } \\
\text { primary school between } 1990 \text { and } 2011(\%)\end{array}$ & ,549 & \\
\hline $\begin{array}{l}\text { Cumulative value of agriculture and rural development } \\
\text { funds per capita between } 2004 \text { and } 2015 \text { (HUF) }\end{array}$ & ,775 & \multirow{2}{*}{$\begin{array}{l}\text { Absorption } \\
\text { ability }\end{array}$} \\
\hline $\begin{array}{l}\text { Development of net income per capita between } 2004 \text { and } \\
2014(\%)\end{array}$ & ,736 & \\
\hline $\begin{array}{l}\text { Development of the commuting volume between } 1990 \\
\text { and } 2011(\%)\end{array}$ & ,966 & Commuting \\
\hline
\end{tabular}

Source: Self edit, 2019.

Factors were named because of the variables that make them up, so the first factor was named "society," the second "absorption capacity," and the third "commuting".

Two variables were included in the "absorption capacity" category; ,the amount of subsidies per capita" and ,development of net income per capita". This is due to the fact that in order to apply for support from the European Agricultural Fund for Rural Development (hereinafter: EAFRD), it is necessary to have a self-financing amount specified in the calls for proposals for the customers requesting support (hereinafter: customer). Furthermore, in the calls of the Rural Development Program 2014-2020, the existence and extent of one's own resources also mattered in addition to the own financial contribution. During the content evaluations, additional points were given to the support applications in which the client had its own resources.

The names of the other two factors were given automatically by the program.

\section{The result of the cluster analysis}

In this research method, settlements were separated according to the cluster categories shown in Table 2. There are 21 settlements marked green on the map (Cluster 1), 37 settlements marked yellow (Cluster 2) and 46 settlements marked brown (Cluster 3 ).

Cluster 1 includes "settlements with fortunate development" for which society is the strongest factor. This means that in these settlements, the population density and the increase in the number of people with higher education diplomas is the highest. On the other hand, unemployment and commuting increased the least compared to the other two clusters. The favorable development of the population density is also supported by the positive development of the migration and natural reproduction indicators. For the purpose of performing the factor analysis, I have already queried these indicators from the National Spatial Development Information System. Since these did not meet the criteria for participation in the analysis, they could not be included in it. The indicators supporting the results described below were also affected by this problem, but I was able to use it to explain and support the results of the cluster analysis. The lower growth of the unemployed and commuters is supported by the number of 
economic actors - therefore the number of workplaces - as well, which increased more than in the case of other groups of settlements. In addition, although the proportion of those who did not complete primary school decreased the least $(0.4 \%)$ in the settlements of this cluster, the base value of 1990 is also the lowest compared to the other two clusters. The volume of subsidies per capita, the change in net income per capita and the indicators of those without primary school education decreased the least. The groups of settlements draw well-visible focal points on the map, of which most of the "settlements with fortunate development" have the status of cities, or are located close to Budapest or Szeged.

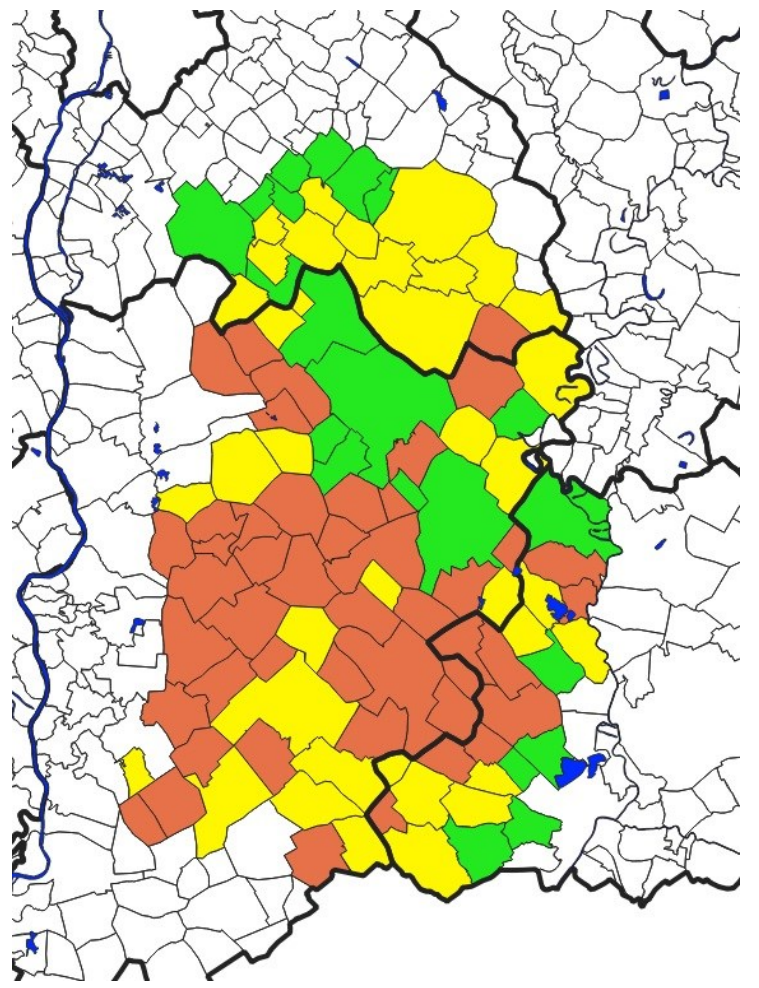

Figure 2: Settlement typing according to three cluster category research Source: Self edit, 2019.

Cluster 2 includes "peripheral settlements" for which none of the indicators were favorable. Regarding the cluster, the commuting factor is the strongest, which is also supported by the very high value of the indicator compared to the other clusters. This value is $16,8 \%$, which is very high compared to the values of the other two clusters $(8,2 \%, 3,7 \%)$. The cluster did not show favorable values for the other indicators either. The values give the impression that the population is trying to compensate and deal with the backwardness of the settlements and their own difficult situation by commuting to workplaces and schools. The unemployment data also shows the worst growth of $3.3 \%$ in this group of settlements. In other words, the inhabitants of these settlements are mobile, but they are either unable or unwilling to move from their place of residence. Whatever causes this phenomenon, it is definitely necessary to better examine the background and treat the issues if possible. In my opinion, because the settlements are less developed, property prices are low, which prevents residents from moving to more developed settlements. My conjecture is supported by the real estate map statistics on the ingatlannet.hu. This is where rural development decision makers need to step in. The name of the cluster was also given by the location of the settlements on the map because the settlements are located in two larger groups. One of the groups is the settlements of South Bács-Kiskun and East Csongrád counties, the other group is in South Pest county. A further reason for the choice of the cluster name is that the indicators are very unfavorable for the settlements belonging to this cluster. 
The third, the "tendering settlements" cluster has the strongest average of the two indicators of the absorption capacity factor. This means that the ,amount of agricultural and rural development support per capita between 2004 and 2015" and the ,value of the change in net income per capita" indicator values are the highest. The settlements of the cluster managed to reduce the proportion of the uneducated the most: by $1.1 \%$ between 1990 and 2011 . The reasons for this may be as follows; suitable education level is essential to win some applications, nowadays the agricultural generational change is an important topic, which makes it a priority for agricultural families, that the next generation have as high as possible level of education. New challenges in agriculture also encourage the existence of the highest possible qualifications. With regard to the net income per capita values, subsidies can play a partially supporting and explanatory role in my view, as a certain degree of one's own financial contribution and / or own resource is essential for launching and implementing tenders. In addition, the number of smallholder farmers is the highest in the settlements of this cluster and had the smallest decrease between 1992 and 2015.

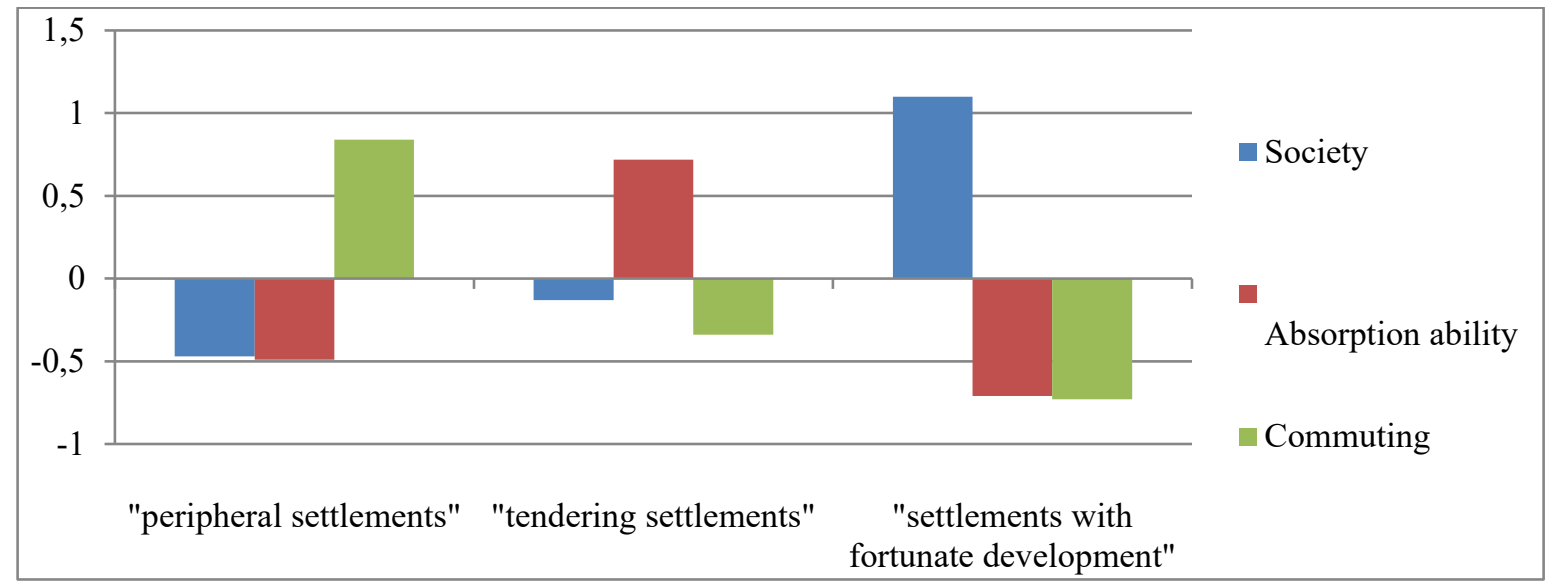

Figure 3: Directions of the restructuring of the settlements of Homokhátság

Source: Self edit 2019.

\section{Conclusions}

The clustering of the settlements of Homokhátság has brought several conclusions, which are as follows;

- The obtained clusters can be clearly seen and delineated on the map.

- The "settlements with fortunate development" cluster is dominated by urban or agglomeration settlements around cities.

- The population density of the cities belonging to the "peripheral settlements" cluster has the largest decrease not only compared to settlemets in other clusters, but also with the settlements belonging to its own cluster. The reason for this is not found in migration, but in the fact that the number of deaths is much higher than births.

- The rate of commuting decreased in 10 settlements out of the 104 examined settlements during the 25 years timeframe. 7 of these settlements belong to the cluster "settlements with fortunate development". However, in the 10 settlements with the largest increase in commuting, 8 are among the "peripheral settlements".

- With regard to "tendering settlements", it does not automatically follow that they are of an agricultural nature, as the number of both agricultural employees and smallholder farmers has decreased significantly. Out of the three clusters, the share of employees decreased the most here; by $11.4 \%$. 
It also follows from the results obtained, that the "settlements with fortunate development", is development, more industrialized and have high proportion of cities $(43 \%)$, they are not able to attract more agricultural and rural development support. This study does not support better wage growth in cities. Moreover, its extent barely exceeds the value of "peripheral settlements".

The "tendering settlements" seem to be trying to seize as many opportunities as possible to break out and / or develop. This is supported by, among other things, the value of real estate prices and the indicators, what I examined. These settlements seem to have enough power for development, their absorption capacity is good. In these settlements have may be the claim for development, they have just need time, that let them be allowed to get in between "settlements with fortunate development".

The settlements of the "peripheral settlements" group are in a difficult situation as they seem to have run out of power so that they cannot use their rural economic resources. They are weak in mobilizing financial support for agricultural and rural development. To help these settlements only with a strong, well-organized, logical leader, a sustainable rural development program, and sufficient financial resources. And these are still not enough, as the settlement must be formed into a responsible community, so that bottom-up initiatives can also be born. Finally, the most important resource should be perhaps the most; time. Because here, in my opinion, not only infrastructural developments, but also necessary to move to positive direction the outlook on life of the population.

According to László Sajtos and Ariel Mitev, since factor analysis is a multivariate procedure, there can be several answers and solutions to the same question, therefore subjective decisions become more valuable when conducting investigations. For this reason, the present results cannot be considered exclusive. However, I believe that they are suitable for getting to know the settlements, the groups of settlements and some of their contexts better and for providing a basis for the decision-makers who want the rural development of the Homokhátság.

\section{References}

1. Csallner A. E. (2015): Bevezetés az SPSS statisztikai programcsomag használatába Szegedi Tudományegyetem Juhász Gyula Pedagógusképző Kar, Szeged, pp. 99.

2. Csatári B. (1999): A magyar vidék térségi tagolódása. I. Vidéki térségek és vidéki települések. Típusalkotás. MTA RKK Alföldi Tudományos Intézete, Kecskemét, pp. 16-17.

3. Fehér A. (2005): A vidékgazdaság és a mezőgazdaság Agroinform kiadó Budapest pp. 21-22.

4. Glatz et al (2004): Homokhátság 2004: szembesítés, lehetőségek, teendők. MTA RKK Alföldi Tudományos Intézete, Kecskemét

5. Káposzta J. (2015): A vidékgazdaság fejlesztési kérdései a XXI. században In: Bíró Zoltán, Gyetvai Árpád, Magyar Ferenc (szerk.) Kreatív fiatalok - innovatív vidék: Sikeres helyi fejlesztési gyakorlatok a Székelyföldön. 188 p. Csíkszereda: Státus Kiadó, 2015. pp. 13-22. (Új utakon a tehetséggondozás VI.) ISBN 978-606-661-0407

6. Káposzta József-Honvári Patrícia (2019): A „smart falu” koncepció föbb összefüggései és kapcsolódása a hazai vidékgazdaság fejlesztési stratégiájához. Tér és Társadalom 2019. 33. évfolyam/1. eISSN: 2062-9923 pp. 83-97.

7. Káposzta József (2020): A vidékfejlesztés helye a regionális tudományban, Tér és Társadalom, 34(1), o. 37-40. eISSN: 2062-9923 
8. Kis K. (2013): Vidékgazdaság, erőforrások, infrastruktúra rendszerszemléletben. In. Veres L. (szerk.): Regionális földrajzi tanulmányok: Abonyiné Dr. Palotás Jolán 70. születésnapja tiszteletére. (Közép-Európai Monográfiák 7.). Egyesület Közép-Európa Kutatására, Szeged. pp. 110-111.

9. Lengyel I.- Rechnnitzer J. (2004): Regionális gazdaságtan, Dialóg Campus Kiadó, Budapest-Pécs pp. 28.

10. Cloke P.J.- Park C.C. (1985): Rural Resource Management, St. Martin Press Inc. New York, USA.

11. Ritter K. (2018): A vidékgazdaság foglalkoztatási szerkezete Magyarországon in: Hadtudományi szemle 11. évf. 4. sz. pp. 400-420. ISSN 2060-0437 DOI: 10.32563/hsz.2020.1.1

12. Sajtos L.- Mitev A. (2007): SPSS Kutatási és adatelemzési kézikönyv, Alinea Kiadó

13. Szűcs Antónia-Káposzta József (2018): A Gyöngyösi járás településeinek komplex fejlettségi rangsora és dinamikája. TERÜLETI STATISZTIKA 58:(5) pp. 489-504. ISSN 0018-7828 